\title{
The invasion of five alien species in the Delta do Parnaíba Environmental Protection Area, Northeastern Brazil
}

\author{
Daniel Loebmann ${ }^{1}$, Ana Cecília G. Mai² \& James T. Lee ${ }^{3}$ \\ 1. Laboratório de Herpetologia, Programa de Pós-Graduação em Ciências Biológicas (Zoologia), Instituto de Biociências, \\ Universidade Estadual Paulista, Av. 24 A, 1515, Bairro Bela Vista, CEP 13506-900, Rio Claro, SP, Brazil; \\ contato@danielloebmann.com \\ 2. Embrapa Meio-Norte, Laboratório de Recursos Aquáticos, BR 343, km 35, CEP 64200-970, Parnaíba, PI, Brazil; \\ anacecilia_mai@yahoo.com.br \\ 3. Laboratório de Biologia Pesqueira e Manejo de Recursos Aquáticos, Universidade Federal do Pará, Av. Perimetral, \\ 2651. CEP 66077-830, Belém, PA, Brazil; james.jtlee@gmail.com
}

Received 20-IX-2009. C Corrected 26-II-2010. Accepted 25-III-2010.

\begin{abstract}
Marine biological invasions have been regarded as one of the major causes of native biodiversity loss, with shipping and aquaculture being the leading contributors for the introductions of alien species in aquatic ecosystems. In the present study, five aquatic alien species (one mollusk, three crustaceans and one fish species) were detected during dives, shore searches and from the fisheries on the coast of the Delta do Parnaíba Environmental Protection Area, in the States of Piauí and Maranhão, Northeastern Brazil. The species were the bicolor purse-oyster Isognomon bicolor, the whiteleg shrimp Litopenaeus vannamei, the giant river prawn Macrobrachium rosenbergii, the Indo-Pacific swimming crab Charybdis hellerii and, the muzzled blenny Omobranchus punctatus. Ballast water (I. bicolor, C. hellerii, and O. punctatus) and aquaculture activities ( $L$. vannamei and $M$. rosenbergii) in adjacent areas are the most likely vectors of introduction. All exotic species found have potential impact risks to the environment because they are able to compete against native species for resources (food and habitat). Isognomon bicolor share the same habitat and food items with the native bivalve species of mussels and barnacles. Litopenaeus vannamei share the same habitat and food items with the native penaeids such as the pinkspot shrimp Farfantepenaeus brasiliensis, the Southern brown shrimp Farfantepenaeus subtilis, and the Southern white shrimp Litopenaeus schmitti, and in the past few years L. vannamei was responsible for a viral epidemics in the cultivation tanks that could be transmitted to native penaeid shrimps. Charybdis hellerii is also able to cause impacts on the local fisheries as the species can decrease the populations of native portunid crabs which are commercialized in the studied region. Macrobrachium rosenbergii may be sharing natural resources with the Amazon River prawn Macrobrachium amazonicum. Omobranchus punctatus shares habit with the native redlip blenny Ophioblennius atlanticus and other fishes, such as the frillfin goby Bathigobius soporator. Some immediate remedial measures to prevent further introductions from ballast water and shrimp farm ponds should be: (i) to prevent the release of ballast water by ship/vessels in the region; (ii) to reroute all effluent waters from shrimp rearing facilities through an underground or above-ground dry well; (iii) to install adequate sand and gravel filter which will allow passage of water but not livestock; (iv) outdoor shrimp pounds located on floodable land should be diked, and; (v) to promote environmental awareness of those directly involved with ballast water (crews of ship/vessels) and shrimp farms in the region. Rev. Biol. Trop. 58 (3): 909-923. Epub 2010 September 01.
\end{abstract}

Key words: exotic species, ballast water, aquaculture, Mollusca, Decapoda, Blenniidae.

Numerous factors have been appointed to explain the disappearance of wild species from their natural habitats. Among them, biological invasions are a leading cause of species extinctions and biotic homogenization in terrestrial and freshwater systems worldwide (Sala et al. 2000, Lockwood \& McKinney 2001, but see Gurevitch \& Padilla 2004 
for marine habitats), ranking second only, to habitat loss as the major threat to biodiversity (Wilson 1992, Wilcove et al. 1998).

The magnitude of the problem is extensive, and invasions frequently interact with other factors such as habitat loss, pollution and climate change compromising the integrity of marine ecosystems. Despite the severity of the implications, studies demonstrating the impacts of introduced species in the marine environment are rare, and most introductions probably go unnoticed (Rilov \& Crooks 2009). Other factors have also been suggested as facilitators of the establishment of invasive species, including high reproductive rates, facilitated dispersal, low levels of competition among resident species, tolerance to a wide range of environmental conditions, often, and lacking predators in their new environment (Crawley 1986, Kolar \& Lodge 2001, Sakai et al. 2001).

Several studies have summarized the impacts of invasive species on native species, and their community structure (Williamson 1996, Wilcove et al. 1998, Parker et al. 1999, Sala et al. 2000, Stein et al. 2000). These studies attributed the main impacts on native biota to the spread of exotic pathogens and parasites, biological competition for space and food, predation upon native species, and alteration of the genetic makeup in closely related species. Moreover, many species listed as threatened or endangered are considered to be at risk primarily because of competition with and predation by non-indigenous species (Wilcove et al. 1998).

Marine and freshwater ecosystems are particularly vulnerable to invasions of alien species as the dispersion of propagules in water occurs easier than in terrestrial environments. Minchin et al. (2009) provide a wide review of the vectors that contribute to the invasions of aquatic alien species and point out eight main pathways for a non-native organism to arrive in a new location. Among these vectors, shipping and aquaculture have been considered as the most critical pathways for marine invasions globally (Molnar et al. 2008). Burke et al. (2000) estimated that the marine ecosystems in the Mediterranean contain 480 invasive species, the Baltic 89, and Australian waters 124. Considering that the number of invasive species is increasing quickly and that undisturbed natural areas are declining, biological impacts by alien species may become the leading factor of ecological disintegration (Crooks \& Soulé 1996).

In Brazil, despite the researchers efforts to try to understand the patterns of dispersion, causes and consequences of bioinvasions, the surveys are very limited. According to Ferreira et al. (2009) there is a clear trend of increasing bioinvasion events in regional coastal ecosystems, but whether invasion rates are actually increasing or are a result of more intensive research efforts in recent years is still an open question. Therefore, to understand and to track the expansion of the bioinvasions in the Brazilian coast, we present new records of occurrence of five aquatic alien species in the Environmental Protection Area and propose guidelines to circumvent further introductions to the coastal zone of the States of Piauí and Maranhão (Northeast Brazil), an ecological sanctuary which supports a rich diversity of aquatic fauna, including commercial and threatened species.

\section{MATERIAL AND METHODS}

Site characteristics: Established on August $28^{\text {th }} 1996$, the Delta do Parnaíba Environmental Protection Area (Delta do Parnaíba, EPA) is located among the pairs of geographical coordinates $02^{\circ} 37^{\prime}-03^{\circ} 05^{\prime} \mathrm{S}$ and $42^{\circ} 29^{\prime}$ $41^{\circ} 09^{\prime} \mathrm{W}$. The area covers $3138 \mathrm{~km}^{2}$, which comprises the entire littoral of the State of Piauí and parts of the littorals of the States of Ceará and Maranhão. The tidal variation in the area is classified as mesotidal (Davies 1964), with a maximum range of $3.3 \mathrm{~m}$. Water temperature is homogenous throughout the area and averages $28.5 \pm 0.9^{\circ} \mathrm{C}($ mean $\pm \mathrm{SD})$. According to Köppen's climate classification updated (Kottek et al. 2006), the area is classified as Aw (Equatorial climate with dry winter). Temperatures are warm throughout the year ranging from 22 to $33^{\circ} \mathrm{C}$ with a marked 
dry period, when precipitation is lower than $100 \mathrm{~mm}$ between June and December, and a rainy period in the first months of the year (January-May).

The coastal zone of the Delta do Parnaíba EPA is formed by a complex mosaic of several habitats such as coastal dunes, rocky shores, mangrove forests, estuaries, and sandy beaches. Three estuaries (Parnaíba River Delta, Camurupim/Cardoso and Timonha/Ubatuba) have important roles in the ecology of the coastal communities due to the release of large amounts of sediments and organic matter, especially in the rainy season. In addition, the Parnaíba River Delta is considered the third largest oceanic deltaic formation worldwide.

Sampling methods: Specimens of the non-native species were recorded from February 2005 to April 2009 in the municipalities of Parnaíba, Luis Correia, Cajueiro da Praia (State of Piauí) and Araioses (State of Maranhão). Individuals were obtained by the following methods: (1) Snorkeling; this method was performed sporadically on the beaches of Barra Grande (Cajueiro da Praia) and Coqueiro (Luis Correia) during the low tide (ca. 2 hours each dive); (2) Intensive search for unfamiliar individuals on rocky outcrops, which was conducted monthly on the beaches of Cajueiro da Praia and Barra Grande (Cajueiro da Praia), and Coqueiro (Luis Correia) during the low tide (ca. 3 hours each search); and (3) Monitoring the local fisheries (casting nets) during the season fishery of the white shrimp (May to July). Total length of each specimen collected was measured. Voucher specimens were fixed in $10 \%$ formalin, preserved in $70 \%$ alcohol, and deposited at the Zoological collection of the Natural History Museum of the Universidade Federal da Bahia (UFBA) and the Crustacean collection of the Fundação Universidade Federal do Rio Grande (FURG). Collecting permits were authorized by the Brazilian Environmental Protection Agency, the Instituto Brasileiro do Meio Ambiente e dos Recursos Naturais Renováveis (IBAMA) (Proc. Number 18027-2).

\section{RESULTS}

Five aquatic alien species (one mollusk, three crustaceans and one fish) new to the study area were identified during the period of this study (Fig. 1), i.e. the bicolor purse-oyster Isognomon bicolor (C. B. Adams 1845), the whiteleg shrimp Litopenaeus vannamei (Boone, 1931), the giant river prawn Macrobrachium rosenbergii (De Man, 1879), the Indo-Pacific swimming crab Charybdis hellerii (A. Milne-Edwards, 1867) and, the muzzled blenny Omobranchus punctatus (Valenciennes 1836).

Mollusca, Bivalvia, Isognomonidae: Isognomon bicolor. In June 2008, the mats of I. bicolor (Fig. 2) were identified attached on granite rock shores at the Pedra do Sal beach, municipality of Parnaíba, State of Piauí (02 $\left.48^{\prime} 10^{\prime \prime} \mathrm{S}, 41^{\circ} 43^{\prime} 46^{\prime \prime} \mathrm{W}\right)$ (Table 1). Pedra do Sal is the only beach on the coast of Piauí with granitic rocks permanently exposed. In addition, the beach is typically reflective with high-energy waves acting on the outcrops. The individuals of $I$. bicolor were found on the same substrates of the native mussels (Mytilus $\mathrm{sp}$.), in small patches (each $<2 \mathrm{~m}^{2}$ ) at the same zone of Mytilus sp.

Crustacea, Decapoda, Dendrobranchiata, Peneidae: Litopenaeus vannamei. During April and May 2009, four specimens of $L$. vannamei (Fig. 3) were collected. The individuals were obtained from casting nets of fishermen in the municipalities of Luis Correia $\left(02^{\circ} 53^{\prime} \mathrm{S}, 41^{\circ} 37^{\prime} \mathrm{W}\right)$ and Cajueiro da Praia $\left(02^{\circ} 55^{\prime} \mathrm{S}, 41^{\circ} 21^{\prime} \mathrm{W}\right)$ (Fig. 1, Table 2). The individuals of $L$. vannamei were found along with two native shrimp species, the Atlantic seabob Xiphopenaeus kroyeri (C. Heller, 1862) and the Southern white shrimp Litopenaeus schmitti (Burkenroad, 1936). Individuals collected were adults ranging from 10 to $12.6 \mathrm{~cm}$ standard length.

Crustacea, Decapoda, Pleocyemata, Caridae: Macrobrachium rosenbergii. In April 


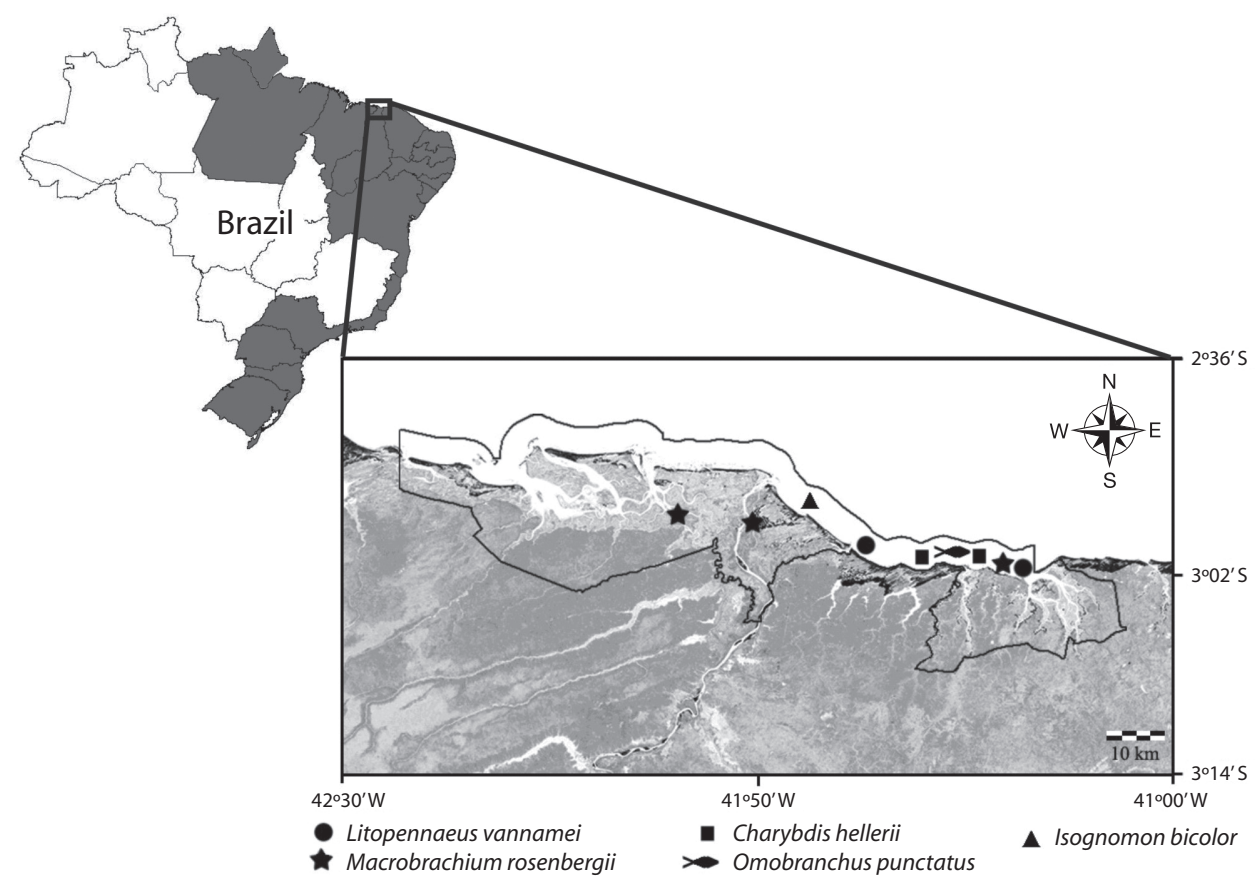

Fig. 1. Delta do Parnaíba Environmental Protection Area showing the location where the alien specimens were captured. In the map of Brazil, the States with coastal zone are in gray color. From North towards South the States in gray are Pará, Amapá, Maranhão, Piauí, Ceará, Rio Grande do Norte, Paraíba, Pernambuco, Alagoas, Sergipe, Bahia, Espírito Santo, Rio de Janeiro, São Paulo, Paraná, Santa Catarina and Rio Grande do Sul.

2009 three adult males of $M$. rosenbergii were detected in Delta do Parnaíba EPA: one specimen collected by a fisherman using a casting net at Barra Grande Beach, in the municipality of Cajueiro da Praia, State of Piauí

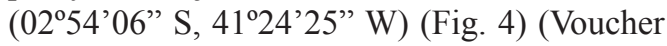
number: UFBA $260 ; 26.8 \mathrm{~cm}$ standard length), one specimen captured by fishermen in Tatus' pier harbor $\left(02^{\circ} 49^{\prime} 56^{\prime \prime} \mathrm{S}, 41^{\circ} 49^{\prime} 48^{\prime \prime} \mathrm{W}\right)$, Ilha Grande de Santa Isabel municipality, Delta do Parnaíba estuary, and a specimen captured by fishermen in the Carnaubeiras, Araioses municipality, border between the States of Piauí and Maranhão (0249'38' S, 41'57'45"

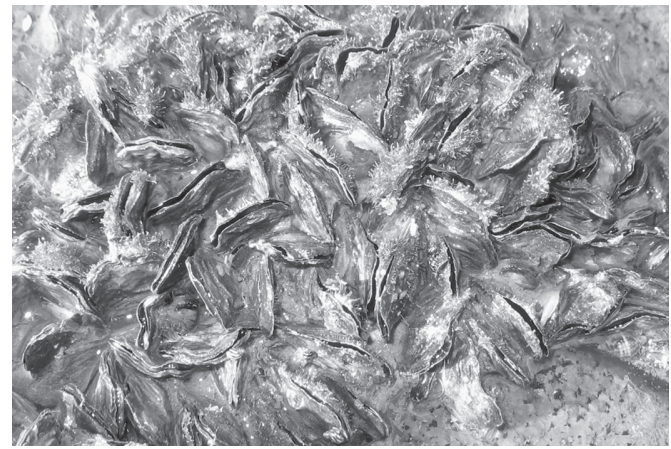

Fig. 2. Isognomon bicolor: Specimen collected at Pedra do Sal beach, State of Piauí, Brazil.

of Piauí (Fig. 5). All specimens were found occupying rock outcrops during the low water (02 $\left.54^{\prime} 10^{\prime \prime} \mathrm{S}, 41^{\circ} 24^{\prime} 21^{\prime \prime} \mathrm{W}\right)$ (Fig. 1, Table 4). Vouchers specimens were deposited in the 
TABLE 1

Isognomon bicolor. Known records, localities and new records (present study) in Brazil. States: PI-Piauí; RN-Rio Grande do Norte; PE-Pernambuco; BA-Bahia; RJ-Rio de Janeiro; SP-São Paulo; SC-Santa Catarina

$\begin{array}{clccc}\text { State } & \text { Munipality } & \text { Latitude }(\mathrm{s}) & \text { Longitude }(\mathrm{w}) & \text { Reference } \\ \text { PI } & \text { Parnaíba } & 02^{\circ} 48^{\prime} 10^{\prime \prime} & 41^{\circ} 43^{\prime} 46^{\prime \prime} & \text { New record } \\ \text { RN } & \text { Natal } & 05^{\circ} 52^{\prime} & 35^{\circ} 09^{\prime} & 1 \\ \text { PE } & \text { Recife } & 08^{\circ} 06^{\prime} & 34^{\circ} 53^{\prime} & 1 \\ \text { BA } & \text { Salvador } & 12^{\circ} 57^{\prime} & 38^{\circ} 21^{\prime} & 1 \\ \text { RJ } & \text { Arraial do Cabo } & 22^{\circ} 57^{\prime} & 42^{\circ} 01^{\prime} & 1 \\ \text { RJ } & \text { Niterói } & 22^{\circ} 58^{\prime} & 43^{\circ} 03^{\prime} & 1 \\ \text { RJ } & \text { Ilha Grande } & 23^{\circ} 05^{\prime}-23^{\circ} 13^{\prime}, & 44^{\circ} 05^{\prime}-44^{\circ} 22^{\prime} & 2 \\ \text { SP } & \text { Ubatuba } & 23^{\circ} 22^{\prime}-23^{\circ} 36^{\prime} & 44^{\circ} 43^{\prime}-45^{\circ} 19^{\prime} & 1 \\ \text { SP } & \text { Ilha Bela } & 23^{\circ} 43^{\prime}-23^{\circ} 58^{\prime} & 45^{\circ} 13^{\prime}-45^{\circ} 27^{\prime} & 1 \\ \text { SP } & \text { Itanhaém } & 24^{\circ} 22^{\prime} & 46^{\circ} 48^{\prime} & 3 \\ \text { SP } & \text { São Sebastião } & 23^{\circ} 46^{\prime}-23^{\circ} 49^{\prime}, 26^{\prime}-45^{\circ} 39^{\prime} & 1 \\ \text { SP } & \text { Bertioga } & 23^{\circ} 47^{\prime} & 45^{\circ} 59^{\prime} & 1 \\ \text { SP } & \text { Guarujá } & 23^{\circ} 58^{\prime}-24^{\circ} 03^{\prime} & 46^{\circ} 10^{\prime}-46^{\circ} 15^{\prime} & 1 \\ \text { SP } & \text { São Vicente } & 23^{\circ} 58^{\prime} & 46^{\circ} 22^{\prime} & 1 \\ \text { SC } & \text { Itapema } & 27^{\circ} 05^{\prime} & 48^{\circ} 36^{\prime} & 1 \\ \text { SC } & \text { Porto Belo } & 27^{\circ} 07^{\prime} & 48^{\circ} 31^{\prime} & 1 \\ \text { SC } & \text { Bombinhas } & 27^{\circ} 08^{\prime}-23^{\circ} 49^{\prime} & 45^{\circ} 26^{\prime}-45^{\circ} 39^{\prime} & 1 \\ \text { SC } & \text { Florianópolis } & 27^{\circ} 37^{\prime} & 48^{\circ} 26^{\prime} & 1\end{array}$

1. Domaneschi \& Martins 2002; 2. Oliveira \& Creed 2008; 3. Jacobucci et al. 2006.

TABLE 2

Litopenaeus vannamei. Known records, localities and new records (present study) in Brazil. States: PI-Piaui; RN-Rio Grande do Norte; SP-São Paulo

$\begin{array}{clccc}\text { State } & \text { Munipality } & \text { Latitude }(\mathrm{s}) & \text { Longitude }(\mathrm{w}) & \text { Reference } \\ \text { PI } & \text { Luis Correia } & 02^{\circ} 53^{\prime} & 41^{\circ} 37^{\prime} & \text { New records } \\ \text { PI } & \text { Cajueiro da Praia } & 02^{\circ} 55^{\prime} & 41^{\circ} 21^{\prime} & \text { New records } \\ \text { RN } & \text { Canguaretama } & 06^{\circ} 22^{\prime} & 35^{\circ} 00^{\prime} & 1 \\ \text { RN } & \text { Nísia Floresta } & 06^{\circ} 07^{\prime} & 35^{\circ} 11^{\prime} & 1 \\ \text { RN } & \text { Sen. Georgino Avelino } & 06^{\circ} 09^{\prime} & 35^{\circ} 07^{\prime} & 1 \\ \text { RN } & \text { Arêz } & 06^{\circ} 12^{\prime} & 35^{\circ} 09^{\prime} & 1 \\ \text { SP } & \text { Cananéia } & 24^{\circ} 57^{\prime}-25^{\circ} 03^{\prime} & 47^{\circ} 48^{\prime}-47^{\circ} 56^{\prime} & 2\end{array}$

1. Santos \& Coelho 2002; 2. Barbieri \& Melo 2005.

Crustacean collection (3208) of the Fundação Universidade Federal de Rio Grande.

Chordata, Osteichthyes, Blenniidae: Omobranchus punctatus. In December 2008, two specimens of $O$. punctatus were collected under the rocks in the intertidal zone at Coqueiro beach $\left(02^{\circ} 53^{\prime} 55^{\prime \prime} \mathrm{S}, 41^{\circ} 34^{\prime} 17^{\prime \prime} \mathrm{W}\right)$ (Fig. 6, Table 5), municipality of Luis Correia
(Fig. 1). These specimens were deposited in the Bahia Federal University Zoological Collection (UFBA 5268). The specimens collected measured 8.2 and $9.0 \mathrm{~cm}$ standard length.

\section{DISCUSSION}

Early detection of invasive species is fundamental to develop management actions to 


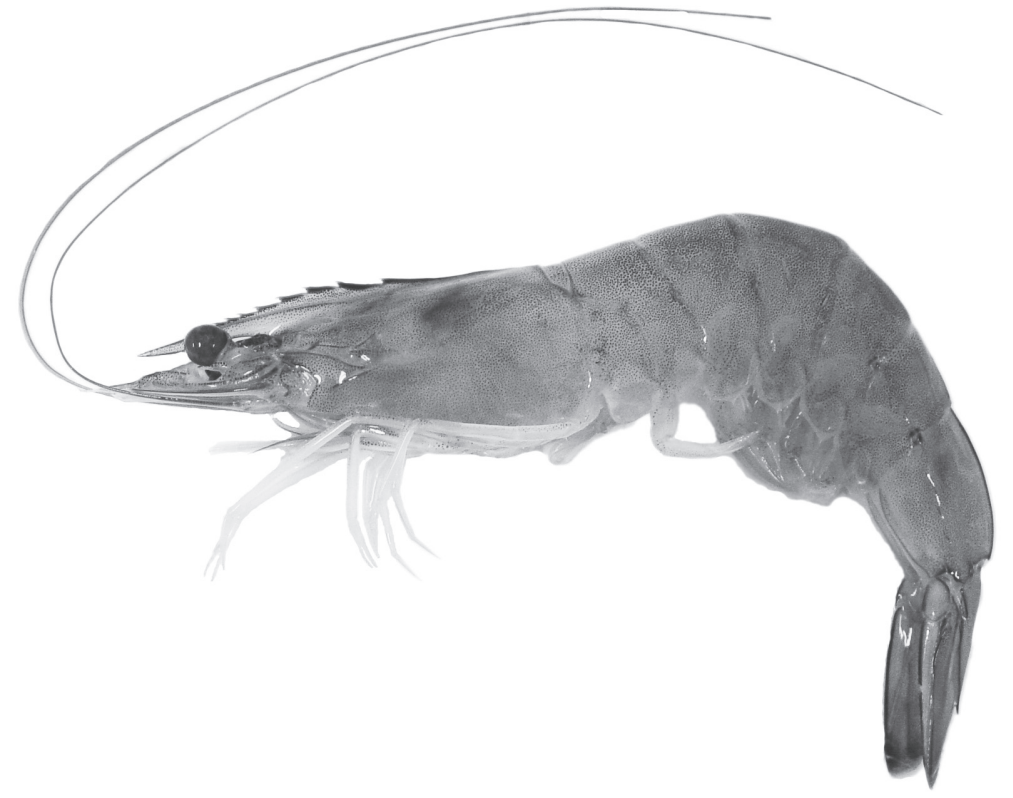

Fig. 3. Specimen of Litopenaeus vannamei with standard length=12.6cm (UFBA 259), collected at Barra Grande beach, State of Piauí, Brazil.

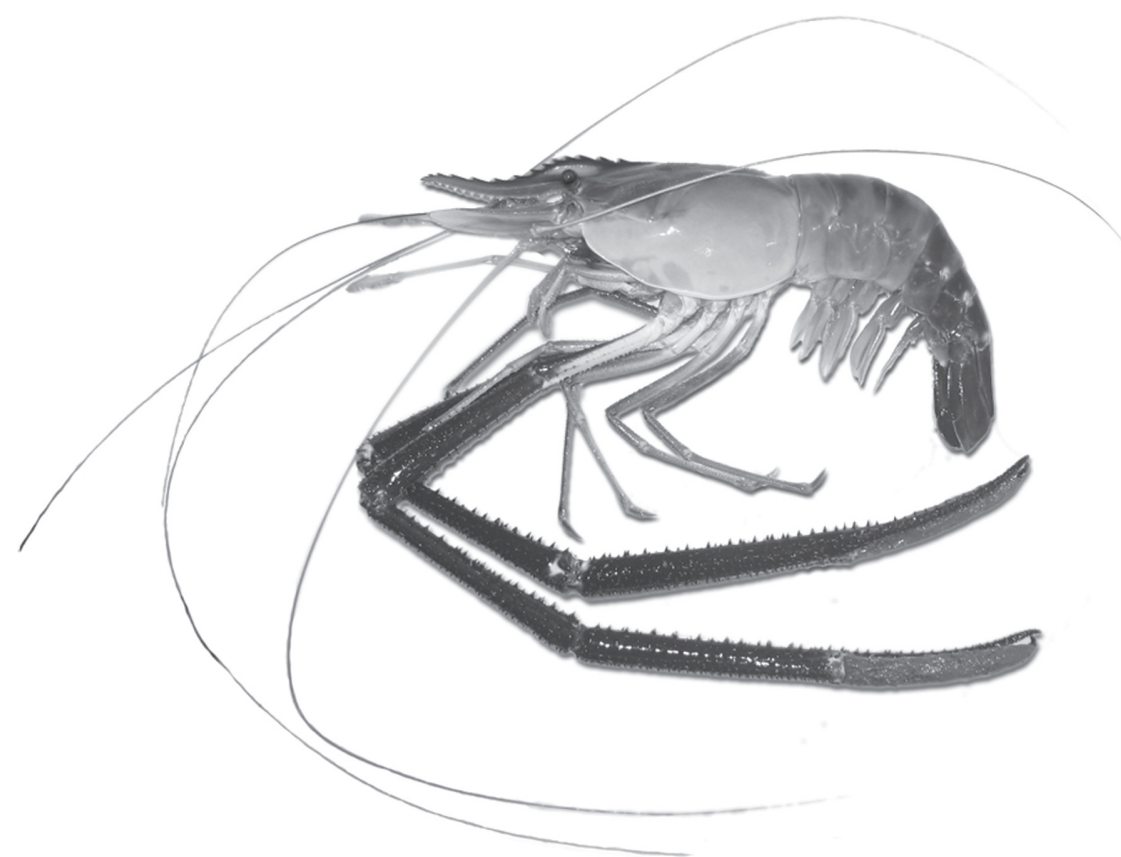

Fig. 4. Specimen of Macrobrachium rosenbergii with standard length=26.8cm (UFBA 260), collected in Barra Grande beach, municipality of Cajueiro da Praia, State of Piauí, Brazil. 
TABLE 3

Macrobrachium rosenbergii. Known records, localities and new records (present study) in Brazil. States: PA-Pará; MA-Maranhão; PI-Piauí; ES-Espírito Santo; SP-São Paulo; PR-Paraná

$\begin{array}{clccc}\text { State } & \text { Munipality } & \text { Latitude }(\mathrm{s}) & \text { Longitude }(\mathrm{w}) & \text { Reference } \\ \text { PA } & \text { Colares } & 00^{\circ} 56^{\prime} & 48^{\circ} 50^{\prime} & 1 \\ \text { PA } & \text { Salvaterra } & 00^{\circ} 45^{\prime} & 48^{\circ} 30^{\prime} & 1 \\ \text { MA } & \text { Araioses } & 02^{\circ} 49^{\prime} 38^{\prime \prime} & 41^{\circ} 57^{\prime} 45^{\prime \prime} & \text { New records } \\ \text { PI } & \text { Ilha Grande } & 02^{\circ} 49^{\prime} 56^{\prime \prime} & 41^{\circ} 49^{\prime} 48^{\prime \prime} & \text { New records } \\ \text { PI } & \text { Cajueiro da Praia } & 02^{\circ} 54^{\prime} 06^{\prime \prime} & 41^{\circ} 24^{\prime} 24^{\prime \prime} & \text { New records } \\ \text { ES } & \text { locality not specifield } & 21^{\circ} 07^{\prime} & 50^{\circ} 10^{\prime} & 2 \\ \text { SP } & \text { Brejo Alegre } & 25^{\circ} 41^{\prime} & 48^{\circ} 31^{\prime} & 3 \\ \text { PR } & \text { Pontal do Paraná } & & 4\end{array}$

1. Barros \& Silva 1997; 2. Valent \& New 2000; 3. Magalhaes et al. 2005; 4. Gazola-Silva et al. 2007.

TABLE 4

Charybdis hellerii. Known records, localities and new records (present study) in Brazil. States: MA-Maranhão; PI-Piaui; CE-Ceará; RN-Rio Grande do Norte; PE-Pernambuco; AL-Alagoas; BA-Bahia; RJ-Rio de Janeiro; SP-São Paulo; PR-Paraná; SC-Santa Catarina

\begin{tabular}{|c|c|c|c|c|}
\hline State & Munipality & Latitude (s) & Longitude (w) & Reference \\
\hline MA & São Luis, Raposa & $02^{\circ} 27^{\prime}-02^{\circ} 30^{\prime}$ & $44^{\circ} 02^{\prime}-44^{\circ} 17^{\prime}$ & 1 \\
\hline PI & Cajueiro da Praia & $02^{\circ} 54^{\prime} 10^{\prime \prime}$ & $41^{\circ} 24^{\prime} 21^{\prime \prime}$ & New records \\
\hline PI & Luis Correia & $02^{\circ} 54^{\prime}-02^{\circ} 55^{\prime}$ & $41^{\circ} 27^{\prime}-41^{\circ} 33^{\prime}$ & 2 \\
\hline $\mathrm{CE}$ & Icapuí & $04^{\circ} 42^{\prime}$ & $37^{\circ} 21^{\prime}$ & 3 \\
\hline $\mathrm{CE}$ & Fortim & $04^{\circ} 27^{\prime}$ & $37^{\circ} 04^{\prime}$ & 3 \\
\hline $\mathrm{RN}$ & Macau & $05^{\circ} 06^{\prime}-05^{\circ} 07^{\prime}$ & $36^{\circ} 15^{\prime}-36^{\circ} 44^{\prime}$ & 4 \\
\hline PE & Tamandaré & $08^{\circ} 44^{\prime}$ & $35^{\circ} 05^{\prime}$ & 5 \\
\hline $\mathrm{AL}$ & Maceió & \multicolumn{2}{|c|}{ locality not specifield } & 6 \\
\hline BA & Salvador & $23^{\circ} 10^{\prime}$ & $44^{\circ} 30^{\prime}$ & 7 \\
\hline BA & Camamu & $13^{\circ} 56^{\prime}$ & $39^{\circ} 05^{\prime}$ & 8 \\
\hline BA & Ilhéus & $14^{\circ} 47^{\prime}$ & $39^{\circ} 01^{\prime}$ & 9 \\
\hline RJ & Rio de Janeiro & $22^{\circ} 46^{\prime}$ & $43^{\circ} 06^{\prime}$ & 10 \\
\hline RJ & Angra dos Reis & $23^{\circ} 02^{\prime}$ & $44^{\circ} 21^{\prime}$ & 10 \\
\hline RJ & Niterói & $22^{\circ} 52^{\prime}$ & $43^{\circ} 06^{\prime}$ & 10 \\
\hline SP & Ubatuba & $23^{\circ} 22^{\prime}-23^{\circ} 36^{\prime}$ & $44^{\circ} 43^{\prime}-45^{\circ} 19^{\prime}$ & 11 \\
\hline SP & Caraguatatuba & $23^{\circ} 37^{\prime}$ & $45^{\circ} 24^{\prime}$ & 11 \\
\hline SP & São Vicente & $23^{\circ} 58^{\prime}$ & $46^{\circ} 23^{\prime}$ & 12 \\
\hline PR & Guaratuba & $25^{\circ} 50^{\prime}$ & $48^{\circ} 34^{\prime}$ & 13 \\
\hline $\mathrm{SC}$ & Florianópolis & $27^{\circ} 48^{\prime}$ & $48^{\circ} 38^{\prime}$ & 14 \\
\hline
\end{tabular}

1. Feres et al. 2007; 2. Lima-Junior et al. 2008; 3. Bezerra \& Almeida 2005; 4. Ferreira et al. 2001; 5. Coelho \& Santos 2003; 6. Calado 1996; 7. Carqueija \& Gouvêa 1996; 8. Almeida et al. 2003; 9. Almeida et al. 2006; 10. Tavares \& Mendonça, 1996; 11. Braga et al. 2005; 12. Reigada et al. 2006; 13. Frigotto \& Serafim-Junior 2007; 14. Mantelatto \& Dias 1999. 


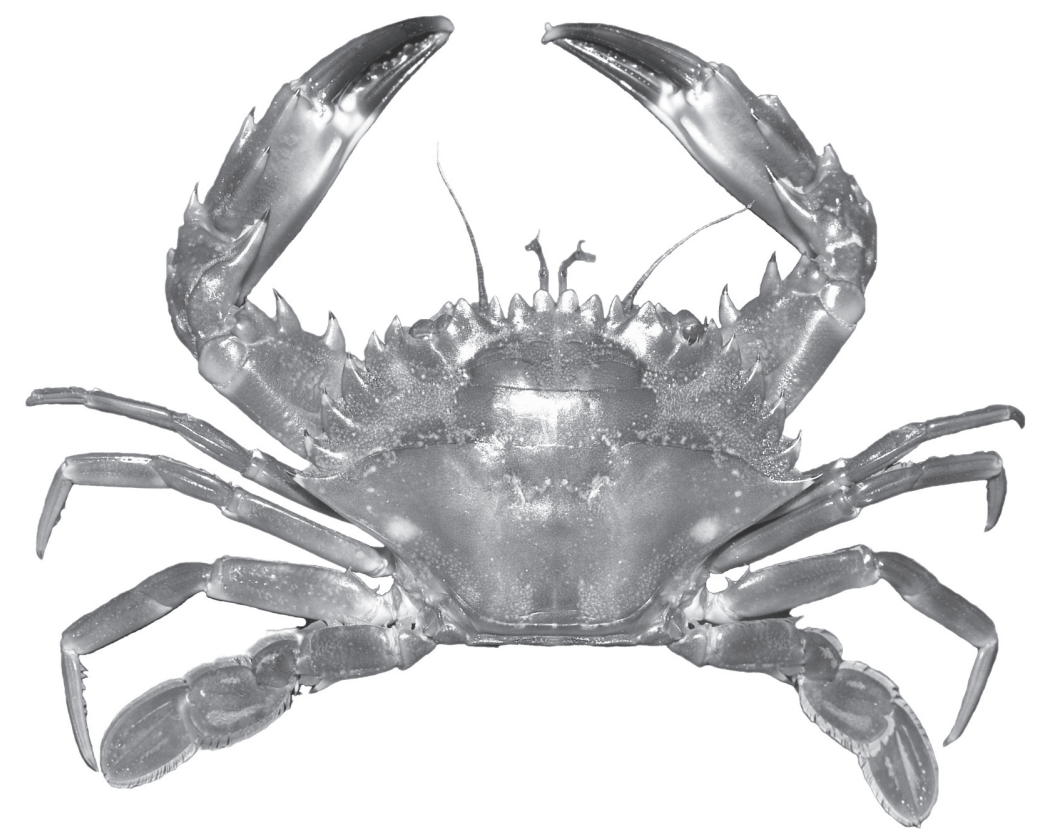

Fig. 5. Specimen of Charybdis hellerii with carapace width=8.0cm (FURG 3208), collected in a tide pool at Barra Grande beach, State of Piauí, Brazil.

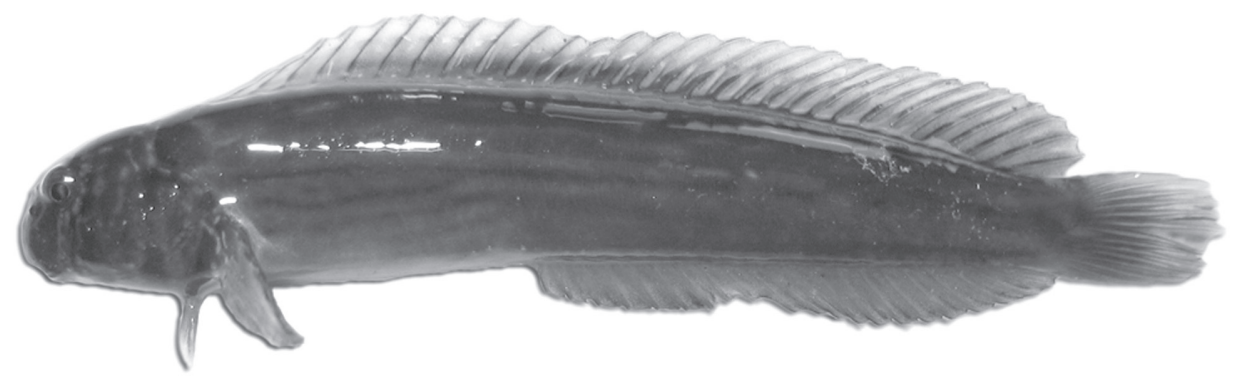

Fig. 6. Specimen of Omobranchus punctatus with standard length=8.2cm (UFBA 5268), collected in a tidepool at Coqueiro beach, State of Piauí, Brazil.

avoid the establishment or to control the spreading of invasive populations. This is particularly important because at early time, measures for contention or eradication are most effective. In the present study, five new occurrences of introduced species, varying from three different phyla, gives an indication of the ecological risks the Delta do Parnaíba EPA currently faces. Accordingly, some aspects of the biology of these species and considerations about their distribution in the Delta do Parnaíba EPA are presented, which could form a baseline for monitoring the impacts of these alien species.

Isognomon bicolor: According to Ferreira et al. (2009) I. bicolor is one of the most important species introduced to the benthic realm along the Brazilian coast. Originally from the 
TABLE 5

Omobranchus punctatus. Known records, localities and new records (present study) in Brazil. States: PI-Piaui; BA-Bahia; RJ-Rio de Janeiro; SC-Santa Catarina

$\begin{array}{clccc}\text { State } & \text { Munipality } & \text { Latitude }(\mathrm{s}) & \text { Longitude }(\mathrm{w}) & \text { Reference } \\ \text { PI } & \text { Luis Correia } & 2^{\circ} 53^{\prime} 55^{\prime \prime} & 41^{\circ} 34^{\prime} 17^{\prime \prime} & \text { New record } \\ \text { BA } & \text { Salvador } & 23^{\circ} 10^{\prime} & 44^{\circ} 30^{\prime} & 1 \\ \text { RJ } & \text { Angra dos Reis } & 22^{\circ} 50^{\prime}-23^{\circ} 20^{\prime} & 44^{\circ} 00^{\prime}-44^{\circ} 45^{\prime} & 2 \\ \text { SC } & \text { São Francisco do Sul } & 26^{\circ} 00^{\prime}-26^{\circ} 40^{\prime} & 48^{\circ} 28^{\prime}-49^{\circ} 00^{\prime} & 2\end{array}$

1. Mendonça et al. 2005; 2. Gerhardinger et al. 2006.

Caribbean region, I. bicolor has been detected in Brazilian waters since 1994 (Domaneschi \& Martins 2002), i.e. in the states of Rio Grande do Norte, Pernambuco, Bahia, Rio de Janeiro, São Paulo, and Santa Catarina (Domaneschi \& Martins op cit., Jacobucci et al. 2006, Oliveira \& Creed 2008) (Table 1). Ballast water and fouling of commercial vessels are the suggested vectors of introduction (Rocha 2002). Another hypothesis is that I. bicolor could have been introduced into Brazil accidentally on oil or gas platforms from the Caribbean coast (Oliveira \& Creed 2008).

At the moment, the impact of this species on native biota in the region seems to be low. However, the species has dominated the midintertidal rocky shores along the Southeastern coast of Brazil (Magalhães 1999, Rapagnã 2004, Breves-Ramos 2004). For example, López (2003) estimated that a population of the native barnacle Tetraclita stalactifera reduced ca. $50 \%$ since the invasion of $I$. bicolor in Cabo Frio, State of Rio de Janeiro. Besides the competition and displacement of barnacle populations, I. bicolor probably competes with a commercial species of Mytilidae, Perna perna, a very abundant mussel found in the region (Rapagnã 2004, Breves-Ramos 2004, Ferreira et al. 2009), which is also an exotic species from Africa that reached the Brazilian coast in the $18^{\text {th }}$ and $19^{\text {th }}$ centuries during the slave trade (Ferreira et al. op cit.).

Litopenaeus vannamei: During the rainy season the probability of shrimp escapes increases considerably because the cultivation tanks, especially those near the rivers, cannot always support the excessive rainfalls. Fig. 7 shows two shrimp farms installed in the surroundings of Camurupim River where some tanks are within $30 \mathrm{~m}$ of the river. Consequently, L. vannamei could be accidentally released from overflowed ponds and lakes into the marine areas.

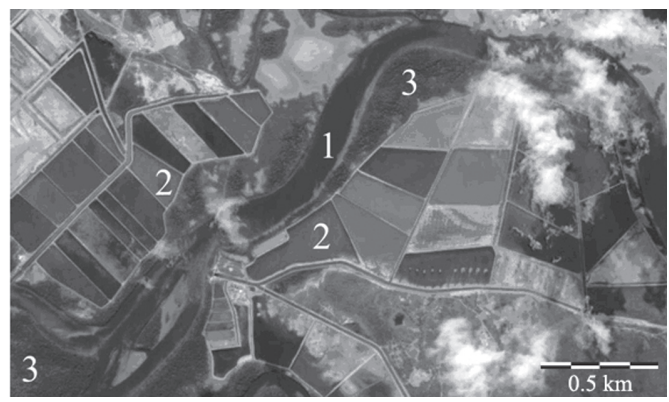

Fig. 7. Satellite image showing the proximity of the shrimp farms (Litopenaeus vannamei cultivation tanks) at the surroundings of Camurupim River (shrimp ponds less than thirty meters of Permanent Preservation Area). 1- Camurupim river; 2- Cultivate shrimp ponds; and 3- Mangrove forests. Image from Google Earth version 5.0.11733.9347.

Litopenaeus vannamei was imported to Brazil in the 1970's for aquaculture purposes. The species was considered the most viable for cultivation compared to native species due to the high adaptability to the varying hydrochemical conditions of the tropical estuaries in Northeast Brazil. At the moment, L. vannamei has been reported in Brazilian estuarine and 
coastal waters from Rio Grande do Norte (Santos \& Coelho 2002) to São Paulo (Barbieri $\&$ Melo 2005) (Table 2). However, the occurrence of this species in the wild may be larger than documented as it is relatively difficult to distinguish $L$. vannamei from native penaeid species such as Farfantepenaeus paulensis, Farfantepenaeus brasiliensis and Farfantepenaeus subtilis. To what extent these fugitive specimens of poorly managed shrimp farms will be able to establish self-sustaining populations in the natural environment is still an open question (Ferreira et al. 2009).

Macrobrachium rosenbergii: The giant river prawn $M$. rosenbergii is the most cultivated freshwater shrimp in the world. It is native to the Indo-Pacific region (Pakistan, Vietnam, Philippines, New Guinea and Australia) (Chan 1998). Macrobrachium rosenbergii was brought to Brazil in 1977 for experimental cultivation purposes by the Department of Oceanography of the Universidade Federal de Pernambuco (Cavalcanti 1998). The species disseminated quickly to the States of Maranhão, Ceará, Pernambuco, Rio de Janeiro, São Paulo, and Santa Catarina (Barros \& Silva 1997, Cavalcanti 1998, Valenti \& New 2000).

Although Macrobrachium rosenbergii lives almost the entire life cycle in fresh water, it is considered an estuarine-depend species since it depends on brackish water to reproduce. According to Ling (1969), the physiological dependence of the larvae to brackish water is an important factor to contribute to the establishment of this species in natural waters. In the Brazilian coast there appears to be no well-established population of $M$. rosenbergii, however, records of occurrence in the wild has been observed for the States of Espírito Santo (Valenti \& New 2000), São Paulo (Magalhães et al. 2005), Paraná (Gazola-Silva et al. 2007) and Pará (Barros \& Silva 1997) (Table 3). The rainy season of 2009 accumulated the highest levels of rain fall since 1974 in coastal zone of Piauí. Considering that this species is cultivated in aquaculture farms around the City of Teresina $\left(05^{\circ} 05^{\prime} 21^{\prime \prime} \mathrm{S}, 43^{\circ} 48^{\prime} 09^{\prime \prime} \mathrm{W}\right)$, it is probable that the incidental introduction was made by escapees from these farms.

Charybdis hellerii: The portunid crab Charybdis hellerii is a voracious Indo-Pacific species. The first documented invasion of $C$. hellerii occurred in Mediterranean Sea after the opening of the Suez Channel in the late $19^{\text {th }}$ century (Galil 1992, Rodriguez \& Suárez 2001). In Brazil, the species has been reported since 1995 (Tavares \& Mendonça 1996) and thus far, the species has been reported from Maranhão (North) to Santa Catarina (South) (Carqueija \& Gouvêa 1996, Calado 1996, Negreiros-Fransozo 1996, Mantelato \& Dias 1999; Tavares \& Mendonça 1996, Carqueja 2000, Ferreira et al. 2001, Almeida et al. 2003, Coelho \& Santos 2003, Bezerra \& Almeida 2005; Braga et al. 2005, Almeida et al. 2006, Reigada et al. 2006, Feres et al. 2007, Frigotto \& Serafim-Junior 2007, Coelho et al. 2008, Lima-Junior et al. 2008) (Table 4). According to Ferreira et al. (2009) two hypotheses should be considered for the presence of $C$. hellerii in Brazilian waters. First, the possibility that the species arrived in Brazil as a result of natural dispersion from populations inhabiting the Caribbean Seas since the mid-1980s. Second, the invasion of Brazilian waters through secondary introduction with ballast water.

Furthermore, Charybdis hellerii might have economic impacts to local fisheries as this species may become a competitor of the native portunid crabs (Callinectes spp.) which are commercialized in the region. Although $C$. hellerii is similar in size with the native portunids, this exotic species has no commercial value (Lima-Junior et al. 2008).

Omobranchus punctatus: The original distribution of the muzzled blenny $O$. punctatus was presumed to be the Indo-Pacific region, ranging from Japan and Australia to the Persian Gulf (Golani 2004). In Brazil, the first occurrences were registered in the States of Bahia, Rio de Janeiro and Santa Catarina (Mendonça et al. 2005, Gerhardinger et al. 2006) (Table 5). 
Omobranchus punctatus arrived into Brazilian waters by ballast or bilge water, hidden inside the fouling of ships (Gerhardinger et al. 2006). However, records presented here may have been an effect of the species dispersion since the maritime transport in the region is restricted to small vessels with limited use of ballast water.

Conservation implications: The introduction of exotic and allochtonous species to local communities and ecosystems has been leading to relevant modifications in the food webs, steady-state populations and changes in the ecosystems functional processes (Rocha $e t$ al. 2005).

Delta do Parnaíba EPA is clearly vulnerable to aquatic bioinvasions. Two probable sources, aquaculture and shipping, are responsible for the introduction of alien species in the Delta do Parnaíba EPA. Litopenaeus vannamei and Macrobrachium rosenbergii are species which likely escaped from surrounding aquaculture farms (Santos \& Coelho 2002, Barbieri $\&$ Melo 2005) and Isognomon bicolor, Charybdis hellerii and Omobranchus punctatus were species likely introduced with ships (Tavares \& Mendonça 1996, Gerhardinger et al. 2006).

Environmental impacts associated with the implementation of non-sustainable practices in shrimp farms have been neglected in favor to immediate socio-economic benefits. Mangrove deforestation for the establishment of cultivation tanks, outflow of highly eutrophic effluents into natural water bodies, and the potential dissemination of shrimp virus diseases to native crustacean populations are among the main impacts caused by aquaculture (Boeger et al. 2005, Ferreira et al. 2009).

Tavares \& Mendonça (2004) have reported the introduction of at least 18 species of exotic decapods in the Brazilian coastline. Five species (28\%) have managed to keep reproductively active populations, Charybdis hellerii, Rhithropanopeus harrisi (Gould, 1841), Pyromaia tuberculata (Lockington, 1877), Macrobrachium rosenbergii (De Man, 1879), and Procambarus clarkii (Girard, 1852). Two species have probably reproduced in Brazilian waters, Pilummoides perlatus (Poeppig, 1836) and Penaeus monodon (Fabricius, 1798); and the remaining 11 species $(61 \%)$ had few individuals recorded in natural environments.

All exotic species recorded in this study have high potential to compete for natural resources against native fauna. Isognomon bicolor share the same habitat and food items with the native species of mussels and barnacles (López 2003, Fernandes et al. 2004). Litopenaeus vannamei share the same habitat and food items with the native penaeids such as the pinkspot shrimp Farfantepenaeus brasiliensis (Latreille, 1817), the Southern brown shrimp Farfantepenaeus subtilis (Pérez Farfante, 1967), and the Southern white shrimp Litopenaeus schmitti (Burkenroad, 1936). Charybdis hellerii share resources (space and food) on rocky shores with several brachyurans such as the masked swimming crab Callinectes larvatus Ordway, 1863, the Rugose swimming crab Callinectes exasperatus (Gerstaecker, 1856), the Dana swimming crab Callinectes danae, the Cuban stone crab Menippe nodifrons (Stimpson, 1859), and the narrowback mud crab Panopeus americanus Saussure, 1857. Macrobrachium rosenbergii may be sharing natural resources with the Amazon River prawn Macrobrachium amazonicum (Heller, 1862). Omobranchus punctatus shares habit with the native redlip blenny Ophioblennius atlanticus (Valenciennes, 1836) and other fishes, such as the frillfin goby Bathigobius soporator (Valenciennes, 1837).

Litopenaeus vannamei brought other threats to native crustacean species. In the past few years, almost all farms with cultivated shrimps in the State of Piauí and adjacent states were suffering from a high incidence of viral epidemics, such as the White spot syndrome (WSS), the Taura Syndrome Virus (TSV), the Infectious Myonecrosis Virus (IMNV) and the Necrotizing Hepatopancreatitis (NHP) (Pantoja \& Lightner 2008). These pathogens are highly lethal to cultivated Litopenaeus vannamei (Briggs et al. 2005) and could be transmitted to native penaeid shrimp populations 
(Overstreet et al. 1997, Briggs et al. 2005). Many species have been reported as susceptible hosts (Penaeus merguiensis De Man, 1888 and Metapenaeus monoceros (Fabricius, 1798), while Palaemon setiferus Olivier, 1811, Euphausia superba Dana, 1852, Metapenaeus dobsoni (Miers, 1878), Parapenaeopsis stylifera (H. Milne Edwards, 1837), Solenocera indica Nataraj, 1945, Squilla mantis L., 1758, Macrobrachium rosenbergii and other crustaceans can act as latent carriers (Flegel et al. 1997, Hossain et al. 2001).

The release of non-native organisms is a federal offense according to Brazilian legislation and ballast water/aquaculture in Brazil should be conducted strictly in accordance with specific regulations, control and effective inspections (Alves et al. 2007). Some immediate remedial measures to prevent further introductions from ballast water and shrimp farm ponds should be: (i) to prevent the release of ballast water by ship/vessels in the region; (ii) to reroute all effluent waters from shrimp rearing facilities through an underground or above-ground dry well; (iii) to install adequate sand and gravel filter which will allow passage of water but not livestock; (iv) outdoor shrimp pounds located on floodable land should be diked, and; (v) to promote environmental awareness of those directly involved with ballast water (crews of ship/vessels) and shrimp farms in the region.

Otherwise, the bicolor purse-oyster, the whiteleg shrimp, the giant river prawn, the Indo-Pacific swimming crab, and the muzzled blenny escapes out of most to the vessels and shrimp ponds will negatively change the native diversity scenario in the future.

In order to understand the real impacts that alien species may cause after introduction to new environments, biological and ecological studies are still necessary. Therefore, the data presented in this study is of notable importance to environmental institutions of the government (Instituto Brasileiro do Meio Ambiente e Recursos Naturais Renováveis and Instituto Chico Mendes de Conservação da
Biodiversidade) which are the managers of the Delta do Parnaíba EPA.

\section{ACKNOWLEDGMENTS}

The authors are grateful to Silmara Erthal (Instituto Chico Mendes de Conservação da Bioversidade) for providing the shapefile of the Delta do Parnaíba EPA. Claudio Sampaio (Universidade Federal da Bahia) and Cleverson R. M. dos Santos (Museu Paraense Emílio Goeldi) for confirming the identifications of some specimens. Maria Cristina Oddone for preparing the spanish abstract of the manuscript. Conselho Nacional de Pesquisa e Desenvolvimento (CNPq) for providing a doctoral scholarship to Daniel Loebmann (grant no. 140226/2006-0).

\section{RESUMEN}

En el Área de Protección Ambiental del Delta Del Río Parnaíba, noreste de Brasil fueron detectadas cinco especies acuáticas invasoras (un molusco, tres crustáceos y un pez): la ostra de dos colores Isognomon bicolor, el camarón patiblanco Litopenaeus vannamei, el camarón gigante de río Macrobrachium rosenbergii, el cangrejo nadador del Indo-Pacifico Charybdis hellerii y el blenio hocicudo Omobranchus punctatus. El agua de lastre (I. bicolor, C. hellerii, y O. punctatus) y la acuicultura (L. vannamei y $M$. rosenbergii) en áreas adyacentes son los vectores de introducción más probables. Todas las especies exóticas encontradas son potencialmente riesgosas para el ambiente ya que son aptas para competir con las nativas por recursos como alimento y hábitat. Charybdis hellerii también podría causar impacto en el recurso pesquero local, al reducir las poblaciones de cangrejos portúnidos nativos, comercializados en el área de estudio.

Palabras clave: especies exóticas, agua de lastre, acuicultura, Mollusca, Decapoda, Blenniidae.

\section{REFERENCES}

Almeida, A.O., P.A. Coelho \& J.T.A. Santos. 2003. New records of decapod crustaceans (Dendrobranchiata and Brachyura) for the state of Bahia, Brazil. Nauplius 11: 129-133.

Almeida, A.O., P.A. Coelho, J.T.A. Santos \& N.R. Ferraz. 2006 Crustáceos decápodos estuarinos de Ilhéus, Bahia, Brasil. Biota Neotrop. 6: 1-24. 
Alves, C.B.M., F. Vieira, A.L.B. Magalhães \& M.F.G. Brito. 2007. Impacts of non-native fish species in Minas Gerais, Brazil: present situation and propects, p. 291-314. In T.M. Bert (ed.). Ecological and genetic implications of aquaculture activities. Springer, Dordrecht, Zuid-Holland, Netherland.

Barbieri, E. \& G.A.S. Melo. 2005. Biodiversity: Litopenaeus vannamei (Boone, 1931) exotic species presence in Cananéia-Iguape-Ilha Comprida lagoon estuary complex. O Mundo da Saúde 30: 654-659.

Barros, M.P. \& L.M.A. Silva. 1997. Registro de introdução da espécie exótica Macrobrachium rosenbergii (De Man, 1879) (Crustacea, Decapoda, Palaemonidae), em águas do estado do Pará, Brasil. B. Mus. Pararaense Emílio Goeldi, série Zoologia 13: 31-37.

Bezerra, L.E.A. \& A.O. Almeida. 2005. Primeiro registro da espécie Indo-Pacífica Charybdis hellerii (A. Milne - Edwards, 1867) (Crustacea: Decapoda: Portunidae) para o litoral do Estado do Ceará. Trop. Oceanog. 33: 33-38.

Boeger, W.A., M. Pie, A. Ostrensky \& L.P. Azambuja. 2005. Identity of the putative agent of the lethargic crab disease (LCD), responsible by massive mortalities of the mangrove crab, Ucides cordatus (Brachyura, Ocypodidae), in Northeastern Brazil. Mem. Inst. Oswaldo Cruz 100: 161-167.

Braga, A.A., A. Fransozo, G. Bertini \& P.B. Fumis. 2005. Composition and abundance of the crabs (Decapoda, Brachyura) off Ubatuba and Caraguatatuba, northern coast of São Paulo, Brazil. Biota Neotrop. 5: 1-34.

Breves-Ramos A. 2004. Distribuição, abundância e estrutura populacional de Isognomon bicolor (Adams, 1845) no litoral do estado do Rio de Janeiro, Brasil. MSc. Thesis, Universidade Federal do Rio de Janeiro, Rio de Janeiro, Rio de Janeiro, Brazil.

Briggs, M., S. Funge-Smith, R.P. Subasinghe \& M. Phi1lips. 2005. Introductions and movement of two penaeid shrimp species in Asia and the Pacific. FAO Fisheries Technical Paper, no. 476, Food and Agriculture Organization of the United Nations, Rome, Lazio, Italy.

Burke, L., Y. Kura, K. Kassem, M. Spalding \& C. Revenga. 2000. Pilot Analysis of Global Ecosystems: Coastal Ecosystems Technical Report. World Resources Institute, Washington, Columbia, USA.

Calado, T.C.S. 1996. Registro de Charybdis hellerii (Milne Edwards, 1867) em águas do litoral brasileiro (Decapoda: Portunidae). B. Est. Ciênc. Mar 9: 175-180.
Carqueija, C.R.G. \& E.P. Gouvêa. 1996. A ocorrência, na costa brasileira, de um Portunidae (Crustacea, Decapoda), originário do Indo-Pacífico e Mediterrâneo. Nauplius 4: 105-112.

Cavalcanti, L.B. 1998. Histórico, p. 17-20. In W.C. Valenti (ed.). Carcinocultura de Água Doce. Tecnologia para Produção de Camarões. IBAMA/FAPESP, Brasília, Distrito Federal, Brazil.

Chan, T.Y. 1998. Shrimps and prawns, p. 851-966. In K.E. Carpenter \& V.H. Niem (eds.). FAO species identification guide for fishery purposes. The living marine resources of the Western Central Pacific. Volume 2. Cephalopods, crustaceans, holoturians and sharks. Food and Agriculture Organization of the United Nations, Rome, Lazio, Italy.

Coelho, P.A., A.O. De Almeida \& L.E.A. Bezerra. 2008. Checklist of the marine and estuarine Brachyura (Crustacea: Decapoda) of Northern and Northeastern Brazil. Zootaxa 1956: 1-58.

Coelho, P.A. \& M.C.F. Santos. 2003. Ocorrência de Charybdis hellerii (Milne Edwards, 1867) (Crustacea, Decapoda, Portunidae) no litoral de Pernambuco. Bol. Téc. Cient. CEPENE 11: 167-173.

Crawley, M.J. 1986. The population biology of invaders. Phil. Trans. R. Soc. B. 314: 711-731.

Crooks, J. \& M.E. Soulé. 1996. Lag times in population explosions of invasive species: Causes and implications, p. 103-125. In O.T. Sandlund, P.J. Schei \& A. Viken. The Trondheim Conferences on Biodiversity. Invasive Species and Biodiversity Management. Kluwer Academic, Trondheim, Sør-Trøndelag, Norway.

Davies, J.L. 1964. A morphogenic approach to world's shorelines. Zeits Fur Geomorph. 8: 127-142.

Domaneschi, C. \& C.M. Martins. 2002. Isognomon bicolor (C.B. Adams) (Bivalvia, Isognomonidae): primeiro registro para o Brasil, redescrição da espécie e considerações sobre a ocorrência e distribuição de Isognomon na costa brasileira. Rev. Bras. Zool. 19: 601-610.

Feres, S.J.C., A.T.L. Lopes \& L.A. Santos. 2007. Primeiro registro de Charybdis hellerii (Milne Edwards, 1867) para o litoral Maranhense-Brasil (Crustacea, Decapoda, Portunidae). Bol. Lab. Hidrobiol. 20: 77-82.

Fernandes, F.C., L.C. Rapaganã \& G.B.D. Bueno. 2004. Estudo da população do bivalve exótico Isognomon bicolor (C. B. Adams 1845) (Bivalvia, Isonomonidae) na Ponta da Fortaleza em Arraial do Cabo-RJ, p. 134-141. In J. Silva \& R. Souza (eds.). Água de 
Lastro e Bioinvasão. Interciência, Rio de Janeiro, Brazil.

Ferreira, C.E.L., A.O.R. Junqueira, M.C. Villac \& R.M. Lopes. 2009. Marine Bioinvasions in the Brazilian Coast: brief report on history of events, vectors, ecology, impacts and management of non indigenous species, p. 459-478. In G. Rilov \& J.A. Crooks. Biological invasions of marine ecosystems: ecological, management, and geographic perspectives. SpringerVerlag, Berlin, Brandenburg, Germany.

Ferreira, A.C., C. Sankarankutty, I.M.C. Cunha \& F.T. Duarte. 2001 Yet another record of Charybdis helleri (A.Milne Edwards) (Crustacea, Decapoda) from the Northeast of Brazil. Rev. Bras. de Zool. 18: 357 358.

Flegel, T.W., S. Boonyaratpalin \& B. Withyachumnarnkul. 1997. Progress in research on yellow-head virus and white-spot virus in Thailand, p. 285-295. In T.W. Flegel \& I.H. MacRae (eds.). Diseases in Asian Aquaculture III. Fish Health Section. Asian Fisheries Society, Manila, Metro Manila, Philippines.

Frigotto, S.F. \& M. Serafim-Junior. 2007. Primeiro registro de Charybdis hellerii (Milne Edwards, 1867) (Crustacea) no litoral do estado do Paraná. Est. Biol. 29: 227-230.

Galil, B. 1992. Eritrean decapods in the Levant. Biogeography in motion. B. l'Instit. Océanogr. 9: 115-123.

Gazola-Silva, F.F., S.G. Melo \& J.R.S. Vitule. 2007. Macrobrachium rosenbergii (Decapoda: Palaemonidae): possible introduction in a costal river of Paraná (Brazil). Acta Biol. Parana 36: 83-90.

Gerhardinger, L.C., M.O. Freitas, A.B. Andrade \& C.A. Rangel. 2006. Omobranchus punctatus (Teleostei: Blenniidae), an exotic blenny in the Southwestern Atlantic. Biol. Inv. 8: 941-946.

Golani, D. 2004. First record of the muzzled blenny (Osteichthyes: Blenniidae: Omobranchus punctatus) from the Mediterranean, with remarks on ship-mediated fish introduction. J. Mar. Biol. Ass. U.K. 84: 851852.

Gurevitch, J. \& D.K. Padilla. 2004. Are invasive species a major cause of extinctions? Trend. Ecol. Evol. 19: 470-474.

Hossain, M.D.S., A. Chakraborty, B. Joseph, S.K. Otta \& I. Karunasagar. 2001. Detection of new hosts for white spot syndrome virus using nested polymerase chain reaction. Aquaculture 198: 1-11.
Jacobucci, G.B., A.Z. Güth, A. Turra, C.A. Magalhães, M.R. Denadai, A.M.R. Chaves \& E.C.F. Souza. 2006. Levantamento da macrofauna associada a Sargassum spp. na ilha da Queimada Pequena, Estação Ecológica dos Tupiniquins, litoral sul do Estado de São Paulo, Brasil. Biota Neotrop. 6: 1-8.

Kolar, C.S. \& D.M. Lodge. 2001. Progress in invasion biology: predicting invaders. Trend. Ecol. Evol. 16: 199-204.

Kottek, M., J. Grieser, C. Beck, B. Rudolf \& F. Rubel. 2006. World Map of the Köppen-Geiger climate classification updated. Meteorol. Z. 15: 259-263.

Lima-Junior, T.B., M.I.C. Aragão, J.P. Silva, G.A.S. Melo \& J.R.S.A. Leite. 2008. Occurrence of two IndoPacific species of Brachyura on the coast of Piauí, Brazil. Bol. Lab. Hidrob. 21: 35-40.

Ling, S.W. 1969. The general biology and development of Macrobrachium rosenbergii (De Man). FAO Fish. Rep. 57: 589-606.

López, M.S. 2003. Efecto de la potencial presa exótica Isognomon bicolor (Adams, 1845) sobre la ecología trófica de Stramonita haemastoma (Kool, 1987) en el intermareal rocoso de Arraial do Cabo, RJ, Brasil. M.Sc. Thesis, Universidad Internacional de Andalucía, Córdoba, Spain.

Lockwood, J.L. \& M.L. McKinney. 2001. Biotic homogenization. Kluwer, Dordrecht, Zuid-Holland, Netherland.

Magalhães, C.A. 1999. Partilha de recursos em guilda de gastrópodes predadores em costões de São Sebastião, SP. Ph.D. Thesis, Universidade Estadual de Campinas, Campinas, São Paulo, Brazil.

Magalhães, C., S.L.S. Bueno, G. Bond-Bunkup, W.C. Valenti, H.L.M. Silva, F. Kiyohara, E.C. Mossolin \& S.S. Rocha. 2005. Exotic species of freshwater decapod crustaceans in the state of São Paulo, Brazil: records and possible causes of their introduction. Biodiv. Conserv. 14: 1929-1945.

Mantelatto, F.L.M. \& Dias, L.L. 1999. Extension of the known distribution of Charybdis hellerii (A. MilneEdwards, 1867) (Decapoda, Portunidae) along the western tropical South Atlantic. Crustaceana 72: 617-620.

Minchin, D., S. Gollasch, A.N. Cohen, C.L. Hewitt \& S. Olenin. 2009. Characterizing vectors of marine invasion, p. 109-116. In G. Rilov, J.A. Crooks \& A. Jeffrey (eds.). Biological invasions in marine ecosystems ecological, management, and geographic 
perspectives. Spring-Verlag, Berlin, Brandenburg, Germany.

Molnar, J.L., R.L. Gamboa, C. Revenga \& M.D. Spalding. 2008. Assessing the global threat of invasive species to marine biodiversity. Front Ecol. Environ. 6: 485492.

Negreiros-Françozo, M.L. 1996. The zoea I of Charybdis hellerii (A. Milne-Edwards, 1867) (Decapoda, Portunidae) obtained in laboratory. Nauplius 4: 165-168.

Oliveira, A.E.S. \& J.C. Creed. 2008. Mollusca, Bivalvia, Isognomon bicolor (C. B. Adams 1845): Distribution extension. Check List 4: 386-388.

Overstreet, R.M., D.V. Lightner, K. Hasson, S. McIlwain \& J.M. Lotz. 1997. Susceptibility to Taura Syndrome Virus of some penaeid shrimp species native to the Gulf of México and the Southeastern United States. J. Invert. Pathology 69: 165-176.

Pantoja, C.R. \& D.V. Lightner. 2008. Enfermedades virales, p. 55-116. In V.Q. Morales \& J. Cuéllar-Anjel (eds.). Guía técnica: Patología e inmunología de camarones pendidos. Programa CYTED Red II-D Vannamei, Panama City, Panama.

Parker, I.M., D. Simberloff, W.M. Lonsdale, K. Goodell, M. Wonham, P.M. Kareiva, M.H. Williamson, B. Von Holle, P.B. Moyle, J.E. Byers \& L. Goldwasser. 1999. Impact: Toward a framework for understanding the ecological effects of invaders. Biol. Invas. 1: 3-19.

Reigada, A.L.D., B.S. Sant'anna, C.M. Zangrande \& R.C. Costa. 2006. Macrocrustaceans of non-consolidated sublittoral of the São Vicente Estuarine Bay Complex, São Paulo state, Brazil. Check List. 2: 84-88.

Rocha, F.M. 2002. Recrutamento e sucessão de uma comunidade bentônica de mesolitoral dominada pela espécie invasora Isognomon bicolor (Bivalvia: Isognomidae) C.B. Adams, 1748 em dois costões rochosos submetidos a diferentes condições de batimento de ondas. MSc. Thesis, Universidade Federal do Rio de Janeiro, Rio de Janeiro, Rio de Janeiro, Brazil.

Rocha, O., E.L.G. Espíndola, N. Fenerich-Verani, J.R. Verani \& A.C. Rietzler. 2005. Espécies invasoras em águas doces - estudos de caso e propostas de manejo. Ed. UFSCar, São Carlos, São Paulo, Brazil.

Rodrigues, G. \& H. Suárez. 2001. Anthropogenic dispersal of decapod crustaceans in aquatic environments. Interciencia 26: 282-288.

Rylov, G. \& J.A. Crooks. 2009. Marine bioinvasions: Conservation hazards and vehicles for ecological understanding, p. 3-11. In G. Rilov, J.A. Crooks \& A. Jeffrey (eds.). Biological invasions in marine ecosystems: Ecological, management, and geographic perspectives. Spring-Verlag Berlin, Brandenburg, Germany.

Sakai, A.K., F.W. Allendorf, J.S. Holt, D.M. Lodge, J. Molofsky, K.A. With, S. Baughman, R.J. Cabin, J.E. Cohen, N.C. Ellstrand, D.E. McCauley, P. O’Neil, I.M. Parker, J.N. Thompson \& S.G. Weller. 2001. The population biology of invasive species. Ann. Rev. Ecol. Sys. 32: 305-332.

Sala, O.E., F.S. Chapin III, J.J. Armesto, R. Berlow, J. Bloomfield, R. Dirzo, E. Huber-Sanwald, L.F. Huenneke, R.B. Jackson, A. Kinzig, R. Leemans, D. Lodge, H.A. Mooney, M. Oesterheld, N.L. Poff, M.T. Sykes, B.H. Walker, M. Walker \& D.H. Wall. 2000. Global biodiversity scenarios for the year 2100 . Science 287: 1770-1774.

Santos, M.C.F. \& P.A. Coelho. 2002. Espécies exóticas de camarões Peneídeos (Penaeus monodon Fabricius, 1798 e Litopenaeus vannamei Boone, 1931) nos ambientes estuarino e marinho do nordeste do Brasil. Bol. Técn. Cient. CEPENE 10: 209-222.

Stein, B., L.S. Kutner \& J.S. Adams. 2000. Precious Heritage: The status of biodiversity in the United States. Oxford University, Oxfordshire, United Kingdom.

Tavares, M. \& J.B. Mendonça Jr. 1996. Charybdis hellerii (A. Milne Edwards, 1867) (Brachyura: Portunidae), eight nonindigenous marine decapod recorded from Brazil. Crustacean Res. 25: 151-57.

Tavares, M. \& J.B. Mendonça Jr. 2004. Introdução de crustáceo decápodes exóticos no Brasil: uma roleta ecológica, p. 59-76. In J.S.V. Silva \& R.C.C.L. Souza (eds.). Água de lastro e bioinvasão. Interciência, Rio de Janeiro, Brazil.

Valenti, W.C. \& M.B. New. 2000. Grow-out systems Monoculture, p. 157-176. In M.B. New \& W.C. Valenti (eds.). Freshwater prawn culture: The farming of Macrobrachium rosenbergii. Blackwell Science, Oxfordshire, United Kingdom.

Wilcove, D.S., D. Rothstein, J. Dubow, A. Phillips \& E. Losos. 1998. Quantifying threats to imperiled species in the United States. BioScience 48: 607-615.

Williamson, M. 1996. Biological invasions. Chapman \& Hall, New York, USA.

Wilson, E.O. 1992. The diversity of life. W.W. Norton, New York, USA. 